\title{
God in Jewish and Fante Religious Thought
}

\author{
Leo Andoh Korsah (iD 1 \& Maxwell Kojo Tsibu (iD) 1 \\ 1 Methodist College of Education, Akyem Asene-Aboabo, Oda- Eastern Region - Ghana.
}

\begin{abstract}
This paper focuses on the Jewish concept of God from the Hebrew Bible and also God in the thoughts of the Fante from Oguaa (Cape Coast). The methodological approaches adopted for the study were phenomenology and the narrative method. Instruments used in the collection of data were observation and semi-structured interviews using the purposive sampling technique. The paper deals with the question of the existence of God, names, and the nature of God from both Jewish and Fante thoughts. Questions about the existence of God are taken for granted in the Hebrew Bible: it is a foundational knowledge embedded in their very consciousness and praxis. The same established understanding is found among the Fante from Oguaa, as expressed in the popular maxim: Obi nkyere abofra Nyame, literally meaning, 'no one shows the child God'. The study contends that the Jewish concept of God in the Hebrew Bible is not much different from God in the life and thought of the people of Oguaa. The paper also brings out some shared similarities and differences between the Jewish and Fante in their conceptions about God. The sharp dichotomy between these two sets of religious groups is that among the Jewish people, there is a consistent emphasis on the oneness of YHWH and exclusive devotion unto him as attested to in the Hebrew Bible whereas in the Fante thought, devotion to the Supreme God is diffused with that of other transcendental beings such as gods and ancestors.
\end{abstract}

Correspondence Leo Andoh Korsah Email: korsleo@gmail.com

Publication History Received 25th January 2021, Accepted 12th February 2021, Published online 19th February 2021.

Keywords: Deity, Fante, Jewish, thought, Oguaa, Religious

\section{INTRODUCTION}

A study of the Jewish concept of God as found in the Hebrew Scriptures and God in the life and thought of the Fante of Oguaa (Cape Coast) is very essential to the general Akan experience of God. The people of Oguaa share views of God which may be compared to that of the Jews. The idea of God as the uncreated creator and the final authority in all matters is native to both the people of Oguaa traditional religion and Jewish religious traditions enshrined in the Hebrew Bible. It is entrenched in their religious beliefs and may be regarded as fundamental to their religious systems. The introduction of Christianity into Africa by the early missionaries has led some scholars to suggest that the concept of God among Africans is based on the Hebrew Bible. On the extreme contrary, an Eighteenth-century Western anthropologist ${ }^{1}$ has expressed an erroneous view that Africans are incapable of perceiving the Supreme Being. The third school of thought is that Africans have a concept of God before the introduction of Christianity into Africa. Taking the indigenous people of Oguaa as an African people, the paper sought to find whether there are any similarities between the Fante concept of God and the Jewish concept of God as found in the Hebrew Scriptures.

Besides, the people of Ogua have names that are distinct and express the idea of the uniqueness of God and reflect the attributes they give to him. He is thought of as the Supreme Being, the one who is first and most important in all things. It is in line with these indigenous thoughts that this paper seeks to investigate if the Fante people of Oguaa and the Jews conceive the Supreme Deity on similar tangents or otherwise.

Even though there are extensive studies on indigenous religions in general and the Akan concept of God

Edwin W. Smith, ed., African Ideas of God, 2nd ed., (London, Edinburgh House Press, 1961),1. 
in particular, there seems to be a neglect of that of the Fante. In this paper, the purpose is not only to share an Akan experience of God from the perspective of the Fante from Oguaa but also to compare such a concept to that of the Jews as perceived through the lens of the Hebrew Scriptures. It includes the attributes and names of God from both Jewish and Fante concepts, a comparative analysis of Jewish and Fante notions of God, and finally a conclusion on the discussion taking into consideration all data used.

\section{Method of Approach}

Phenomenological and narrative approaches underline this study. Instruments used in the collection of data were observation and semi-structured interviews. The purposive sampling technique was used to identify key people for the interview. In this regard, the views of some Fante elderly people, traditional priests, and court historians were sought. Data was also gathered from secondary sources including the Jewish Scriptures. Content and comparative analysis were used in analysing data from textual documents, interviews, and observations.

\section{Religious Concepts}

A concept is an abstract idea or a general guiding principle that determines how a person or culture behaves, or how nature, reality, or events are perceived. ${ }^{2}$ To believers of various religions and other ideological bodies, concepts are not just abstract ideas but concrete thoughts realized in beliefs, actions, and rituals. These abstract notions are usually conceived and objectified through cognition processes and sometimes are given mental representations that capture the peculiar abilities associated.

Both classical and contemporary theorists and philosophers have sought to clarify what may count as a concept; how it operates in various contexts and its relevance in helping to understand the human person who comes up with these mental representations. Platonic realists generally see concepts as an abstract object or innate ideas which are instantiations of a transcendental world of pure forms that lay behind the veil of the physical world. ${ }^{3}$ For Kantian philosophers, humans translate mental images into concepts through comparison, reflection, and abstraction. They posit that all categories of apprehension, as well as the more localized concepts, are instruments, subject to revision, through which people attempt to grasp what they can of reality. ${ }^{4}$ For instance, there exists a deep-seated and universal religious urge in humankind that leads people to try to grasp and speak about divinity in terms of human concepts. Cognitive linguists theorize that concepts are concrete metaphors derived from embodied experiences and that they cannot exist independently without their metaphors. ${ }^{5}$ From these explanations, it can be deduced that a concept acts as a powerful gravitational force giving people grounded hopes that drive them to navigate their ways through the slippery and unstable spaces in life.

\section{The Concept of God}

The concept, "God" or "gods" is an abstract label and/or a generic name for the subjective transcendental reality, mostly super-sensible force(s) recognized as the supreme and ultimate recipient(s) of cultic worship in almost every religious tradition. The notion of God or gods is first and foremost an a priori knowledge whose entity exists outside believers' knowledge and personal and communal experiences. However, human interaction with the material world leads them to associate certain attributes, qualities, or characteristics to this empirical thought who is seen as the sources of everything, including knowledge or consciousness itself.

In a well-known fragment, Xenophanes of Colophon, a pre-Socratic Greek philosopher, is reported as having commented that if oxen, horses, and lions were to depict the gods, the horses would picture them as horses, the oxen as oxen, and the lions as lions. At a glance, one would infer that Xenophanes undoubtedly is saying that humans tend to anthropomorphize and depict their notion of the gods (or, in monotheism, the one God) in human terms. When speaking of transcendent being(s), religious people transcribe in a more mundane fashion, and in terms as close as possible to their own experience of something which is really beyond their capacity to grasp. In another breath, Xenophanes' remark is philosophically a foundational inquiry into the concept of God, which thinkers of both the Human and Natural Sciences have been wrestling with throughout the centuries. What is the being(ness) of that which is conceived as 'God'? How do religious people concretize their notion of God? How do names and attributes which are given to 'God' reveal peoples' understandings or conceptions about the nature of this being? In what various ways do religious people depict their 'notion of God' and how do they relate to these depictions? This part of the study explores the complex conceptions Jewish people have about their 'God' as put forward in the Jewish Scriptures.

\footnotetext{
Microsoft Encarta Dictionary. Microsoft Corporation, 2008.

Stephen Laurence \& Eric Margolis, Concepts: Core Readings. (Massachusetts: MIT Press 1999), 3-83.

Sachidanand Prasad, The concept of God in the Philosophy of Kant. (India, New Delhi: Classical Publishing Company, 2005).

John Hick, Philosophy of Religion. (N. J: Eaglewood Cliffs, 1983).
} 


\section{Jewish Concept of God}

God stands as the central pillar of almost all theistic thoughts, but what kind of being is conceived as God by Jewish religious people of the Hebrew Bible? Theologians and philosophers have given a vast array of different answers to this question; and their different answers have shaped - and been shaped by - their different approaches to religion as a whole. According to Ross, there is a personalist concept of God in the Hebrew Bible. ${ }^{6}$ Traditional interpretations of Judaism generally emphasize that God is personal yet also transcendent, while some modern interpretations of Judaism emphasize that God is a force or ideal. For instance, philosophically enlightened Jews such as Maimonides held that God exists "but not through an existence other than His essence" and that he is one "not through oneness." Despite rich insights, Historical-Critical inquiry has unearthed concerning the production history and historical contexts of biblical narratives, passages, and books, the Hebrew Bible still presents perplexing challenges to readers about the notion of God.

The first sentence of the Jewish Bible confirms not just the existence of God but emphasizes his primal attribute as the creator par excellence. The Jewish cosmogonic myths contained therein do not explain how long 'God' existed and where he lived before the creation of the cosmos. Nevertheless, a close examination of these texts in the light of their historical experiences would provide insights into how the Jews conceptualized God's nature - especially his oneness in connection with other gods or angels he lives with and interacts with within the heavenly realm.

From numerous primeval narratives of the Hebrew Bible, one notices that 'God' or YHWH God interacts with other divine beings or gods. Genesis 1:26 is the foremost text which recognizes the presence of other immortal beings living with $E l$ before the creation of humankind (and the world). The tone of YHWH's statement suggests unity and friendliness between him and other divine entity(ies) at the scene. In Genesis 3:22, YHWH God takes counsel with his colleague divine entity(ies) about what Adam and the woman have become. In another story at Genesis 6:1-6, the Yahwist writer also preserves a legend of marriages between the 'Sons of God' (or 'Sons of the Gods') and the 'Daughters of Man' ( $o r$ 'Daughters of Men'). Again, the prologue to the Book of Job ushers readers to a heavenly court or divine Assembly, where the 'Sons of God' or 'Sons of the Gods' or, simply, 'Gods' have presented themselves before YHWH. Against such background, "you Gods" referred to at Psalm 29:1-2, 7-8 is observed. ${ }^{8}$ These varied yet related instances reveal that the Jewish religious person conceives YHWH as the sovereign deity who reigns supreme over both mortals (humans) on earth and immortal entities or gods in the heavenly realm.

At one time in Israel, ${ }^{9}$ YHWH was worshipped as a member of a pantheon. Again, there was a classical Rabbinic idea of "two powers in heaven" (shetei rashuyyot), which clearly implies two divine authorities living side by side. These 'two Gods' were not dualistic entities but "binitarian" Gods who rule side by side and together in different degrees of agreement and correlations, a precursor of the Christian dogma of the "trinitarian" conception of God. ${ }^{10}$

It seems apparent that monotheism was neither at the beginning of the Jewish religion nor does it represent the final apex of its linear development. Commenting on the ambiguous nature of the earlier notions of the oneness of God, Johnson contends that Jewish people had 'the One' and 'the Many' conception of God. "In Jewish thoughts," Johnson further observes, "God was conceived as having an effective indefinable 'extension' of his personality." 11 Any manifestation of unusual vigour which marked a man out as an exceptionally powerful personality, such as the resolution of Gideon (Judg. 6:34), the prowess of Samson (Judg. 14:6, 19; 15:14), the infectious behaviour of the early prophets (1Sam.10:513; 19:18-24) or the qualities of a firm ruler (Isa. 11:2), might be attributed to the influence of the spirit of Yahweh. These instances show that Jews thought in terms of the 'spirit' as an 'extension' of Yahweh's personality which enables him to exercise a mysterious influence upon humankind. In the familiar passage of Isaiah 4:10ff, the "word" is conceived as a potent 'extension' of Yahweh's personality.

Another classical example that illustrates Jews' notion about the 'extension' of Yahweh's extraordinarily powerful personality is the role served by the Ark of the Covenant. Apparently, prior to being carried into battle, the Ark was addressed in quite a personal fashion as found in Numbers 10:35ff: "Arise, Yahweh, that Thine enemies may be scattered; That they that hate Thee may flee before Thee!" Similarly, on its return, it was hailed with the cry: "Return, Yahweh, unto the ten thousand families of Israel." In a battle with the Philistines at Aphek (1Sam. 4:5-8), the opponents identified the Ark with Yahweh - whether the reference is to a "God" or to "Gods." Other instances point to the ambiguity of reference as between the Ark and Yahweh. From the fluidity of references, one can suggest with a high degree of plausibility that the Jew conceptualised his/her God to be 'Many' and at the same time 'One.' Thus, the

\footnotetext{
Jacob Joshua Ross, The primacy of the Personalist Concept of God in Jewish thought. The Journal of Jewish Thought and Philosophy, 8, (1999): 171-199. Moses B. Maimonides, Guide of the perplexed. Translated and Edited by Shlomo Pines. (Chicago: University of Chicago Press, 1963.)

8 Give to YHWH, ye Gods, give to YHWH glory and strength; Give to YHWH the glory due to His Name: Bow down to YHWH in holy array. Who in the clouds doth equal YHWH, is like YHWH among the Gods, A God Who is terrible in the Council of the Holy Ones, Greater and more dread than all those about Him?

Specifically, in the Jewish colony at Elephantine so late as the fifth century B.C.

Peter Schäfer, Two Gods in Heaven: Jewish conception of God in antiquity. (New Jersey: Princeton University Press, 2020).

Aubrey R. Johnson, The one and many in the Israelite conception of God. (Cardiff: University of Wales Press, 1961).
} 
Jewish people made oscillation between the One and Many in their conception of Yahweh. ${ }^{12}$

\section{Expression of the Jewish Concept of God}

Ancient Jewish culture, like the neighbouring nations, looked upon names as an integral part of the thing named, identical, and descriptive of the nature of the name bearer. ${ }^{13}$ Any appreciation of Jewish notion(s) about the nature of their supreme divinity may have to recourse to the important names through which the deity is known, addressed, and worshipped. Basically, such labels establish the identity and reveal the character of the deity. The essence of knowing the name of a deity was considered an important step to getting access to its power. When Moses asked God for his name, God replied, "I Am That I Am", followed by "I Am", and finally "YHWH": "I Am That I Am [Ehyeh Asher Ehyeh...]. Thus, shalt thou say unto the children of Israel, I Am hath sent me unto you. [...] YHWH, God of your fathers, [...] this is My name forever" (Exodus 3:13-15).

The Hebrew word 'YHWH' is a consonantal tetragrammaton. At some point in their history, it became taboo to pronounce the sacred YHWH aloud. This explains why the original pronunciation of YHWH got lost many centuries ago in Judaism. Believers rather preferred to pronounce other titles such as "LORD" (in Hebrew Adonai, in Greek Kyrios) as the substitute of YHWH. However, available evidence ${ }^{14}$ indicates that it was in all likelihood sounded like "Yahweh".

The name YHWH is a verb form derived from the Biblical Hebrew triconsonantal root (היה h-y-y) "to be". Essentially, it means "beingness", "pure existence", or "I Amness." By implication, YHWH disclosed himself to Moses and him as the "isness" of everything or the "beingness" in everything that has being, and the existence of everything that exists. ${ }^{16}$ Because YHWH is the essential presence in all that is present, he is thought of as omnipresent, and because he is the consciousness in everything conscious, he is, by implication, an all-knowing being. In Jewish religious thought, there is nothing that could be hidden from YHWH's awareness since every cognitive process invariably has its roots in the 'I Am' concept. Again, YHWH's omnipotence is derived from the fact that no activity is possible without the "I Am" consciousness. YHWH is the infinite possibility of all potentiality. According to Schmaus, "in the word YHWH" expresses God's activity and active relationship towards his chosen people. ${ }^{17}$

The history of Jewish religious thought in the Hebrew Bible depicts a gradual and progressive understanding of the meaning and implications of YHWH's self-revelation to Moses (Ex. 6:2-3). Likely, this idea of YHWH God evolved gradually from the Canaanite El, who was in all likelihood the high God of Abraham's local deity known as 'Elohim.' This may explain why there are consistent attempts at directing the Jewish believers to render absolute allegiance to only YHWH, not the other manifestations of the divine essence (Ex 20:3; 34:14). The liturgical creed which every Jew recites twice daily places an emphasis on the oneness of YHWH and makes it explicit: "Hear, O Israel: YHWH our (El) YHWH is One. And thou shall love YHWH thy God with all thy heart, with all thy soul, and with all thy strength" (Deut. 6:4-5).

For Obiorah, "the text does not say that YHWH is the only God, rather it only affirms the uniqueness, singleness of the name." 18 The Hebrew numerical masculine singular ehad is generally translated as "one." However, its usage in the text does not exclude the existence of other gods; it is rather concerned with the "oneness of YHWH, oneness of cult, and oneness of place of worship - the Temple in Jerusalem." ${ }^{19}$ Among multiple gods, the Jewish Bible asserts the supremacy and oneness of YHWH. With the formation of the Israelite's federate, YHWH came to be conceived not only as a their national deity but also as the supreme God of the entire universe and human race. The passage at Isaiah 44:67 perfectly captures this notion: I am the first and I am the last; besides me, there is no god. Who is like me? Let them proclaim it, let them declare and set forth before me. Who has announced from of old the things to come? Let them tell us what is yet to be." The key mental attitude expected of the Jewish worshiper is 'knowledge of YHWH'. Numerous texts bear out the point beautifully (1Sam 3:6; Ps. 92:14; Josh 24:31; Is. 1:3; 5: 12-13; Hos. 4:6; Jer. 9:24).

Closely related to 'knowledge of YHWH' as a basic mental conception of their God, the Jews also conceived YHWH as having manifested himself as a personal being in the practice of kindness, justice, and righteousness on the earth (Jer. 9:24). They did not conceive YHWH as possessing a body of flesh and bone, but as a fiery substance (Deut. 4: 24,36$)$ that could fill all space or contract itself within a cloud, or within so narrow a space as that between the figures of the cherubim alongside the Ark in the Temple of Solomon. Though the personality of YHWH was conceived

12 Johnson, The one and many in the Israelite conception of God.

13 Roland Vaux, The religion of the O.T. In R. Tricot (Ed.), New Catholic Encyclopaedia (Vol. 6, Part 2, pp. 393-422). (Washington D.C: Catholic University of America, 1967).

14 Patrick D. Miller, The Religion of Ancient Israel. (Westminster: John Knox Press, 2000), 2.

15 Francis Brown, Samuel Rolles, Driver \& Charles Augustus. Briggs, A Hebrew and English Lexicon of the Old Testament. (England: sn, 1907$), 217$.

16 Charles Ogada, The Judeo-Christian God. In E. E. Onyedinma (Ed.), Whose God is God? Exploring the Concept of God within Religions. (Abuja: Adonis \& Abbey Publishers Ltd, 2013).

17 Michael Schmaus, DOGMA 2: God and Creation. (London: Sheed and Ward Inc, 1969), 16.

18 Jerome Mary, Obiorah, The Biblical foundations of Christian Monotheism. In B. U. Ukwuije (Ed.) God, Bible and African Traditional Religion - Acts of SIST International Missiological Symposium. (Nigeria, Enugu: SNAAP, 2010). 136.

19 Ogada, The Judeo-Christian God. 
as immeasurably greater, and his ways and purposes infinitely more exalted than those of man (Isa. 55: 8-9), in essence, YHWH's personality was regarded as analogous to those of man at his best. They conceived God in what is visible and tangible rather than in what is invisible, unknowable, and ineffable. He was thought of in functional terms rather than in a substantive sense. The functional meaning of the term "YHWH" is most unmistakably implied in the story of Elijah's challenge to the worshippers to prove that Baal is an authentic god. When his appeal to YHWH to answer his prayer was answered, the entire people cried out "YHWH is the God!"

Another important way the Jews conceives deity is through anthropomorphic personalisation. The biblical histories of Jewish people indicate that YHWH revealed himself to Moses and established a solemn pact with the people: where the Jews became YHWH God's elected race and YHWH God as their one and only supreme deity. In their trajectories of life, YHWH is personified with familial and royal metaphors as a wife, a father, a mother, guardian, counsellor, protector, deliverer, defender, king of kings, etc. The Jews, on the other hand, depict themselves metaphorically as Yahweh's wife, sons, and daughters, pride, etc. whom he has loved, cared for, breastfed, and established among the nations.

Like in all ancient cultures of the time, Jewish people saw in YHWH the supreme powers capable of giving them victories in battles and liberation from the hands of enemies. He was thought of as an unquestionable source of religious rituals (i.e., circumcision, Passover, a meditation on the Laws, etc.), social values (i.e., procreation, marriage, the sanctity of life, etc.), and morality (i.e., love for God and neighbours, justice, kindness, and faithfulness, etc.) in the Jewish community. For instance, the 'breath of life' or the animating force in the human being is believed to originate from YHWH. They explained every bit of their historical realities in the providential knowledge of God. Painful experiences are interpreted as just purificatory punishment from Yahweh to awaken their consciousness about the need to keep faithfulness with Yahweh. Likewise, they interpreted their joyful moments as a sign of Yahweh's unique grace and love for the Jewish nation, not necessarily because of their covenantal obedience.

The threefold attributes of a sovereign God - absolute goodness, absolute power, and intelligibility - in the Jewish Bible were not subjected to any positivist appraisal to suggest that 'if these attributes were made to stand in a logical relation to one another, the conjunction of any two of them would exclude the third. ${ }^{20}$ On the contrary, theological interpretations of the prophets and rabbis on the exilic experience and other defeated moments of the Israelites attribute these woes to Israel's unfaithfulness and disobedience. Instead of living by the moral dictates of YHWH, Israel lived 'adulterous lives'; instead of letting' justice and mercy flow like milk', they denied it to the weak and poor; and instead of leaning only on Yahweh for counsel and military intelligence, they placed their trust in the irons of Egyptian and Babylonian powers. The piously religious Jew never conceived that YHWH's power is seen as limited by something whose being in its own right and whose power to act on its own authority He himself acknowledges. Throughout the Hebrew canon, YHWH's sovereignty as all-loving, all-knowing, and all-powerful is asserted, defended in the face of complex realities that seemed to put these notions into question.

Thus, even though the pious Jewish believer would not have had any immediate material representation of Yahweh, their personalised concept of Yahweh found in their daily expressions, liturgical performances, gives far more vivid insights into their notion about God and the proximity between them and YHWH God. In the Bible, Jews' notion of God has shaped and re-shaped other ideas that governed their lives - ideas about power, freedom, time, meaning, and politics, just to name a few.

\section{The Indigenous Religion of the Oguaa People}

The people of Oguaa have been known to be religious since antiquity but there is no specific person that can be identified as the founder of their indigenous religious ideas. This is because, like most indigenous religions, the religious notions and rituals of the Oguaa people emanated gradually from their engagement with the world in their quest for meaning in life. Some essential features mark off the Fante indigenous religion from Judaism, which is a revealed faith. The indigenous Oguaa people acknowledge the existence of a Supreme deity alongside lesser deities/divinities and ancestors.

"The ancestors are those who were morally upright while living, fulfilled their mission in the community and died natural and peaceful deaths. ${ }^{21}$ Asare-Danso extrapolates from Pobee ${ }^{22}$ to suggest that ancestors were members of the clan and have ended their course of journey on earth and have gone ahead to live in the other world. They are revered and honoured as custodians of the land. ${ }^{23}$ This belief is common to all African indigenous religious practitioners.

The Oguaa people also believe in smaller deities/divinities. They are regarded as the children of the Supreme Being and derive their powers from him for specific duties that he assigns to them. The Oguaa traditional religious

\footnotetext{
20 Hans Jonas, The Concept of God After Auschwitz: A Jewish Voice. New School for Social Research. The (University of Chicago, 1987 ), 9.

21 Leo Andoh Korsah \& Jonathan E.T. Kuwornu-Adjaottor. The Akan experience of God through the eyes of the Fante from Oguaa. Art Human Open Acc J. 3(6), (2019); 280-283. DOI: 10.15406/ahoaj.2019.03.00142, 280.

22 John S. Pobee, Toward an African theology (Nashville: Abingdon Press, 1979).

23 Seth Asare-Danso, African Traditional Religion (Cape Coast: Beret Outlook Press, 2019), 36.
} 
practitioners acknowledge seventy-seven deities as the children of the Supreme Being. ${ }^{24}$ These are spirits that have personal names and dwell in stones, rocks, trees, groves, and so on. They are regarded as agents of God and protect all inhabitants of Oguaa. These spirits steer the affairs of the Oguaa traditional area and also the success of the Oguaa fetu afahy $\varepsilon^{25}$ depends on them. At every festival, sacrifices are offered to all the spirits at their various shrines. The people are also of the belief that the earth is a goddess created, and has the name Asaase Afua. She has been put in charge of farming by the Supreme Being. The people of Oguaa acknowledging the existence of other deities besides the supreme being does not make them polytheistic. To refer to them as polytheists will be a hasty conclusion, it is better to classify their religion as henotheistic because the other deities are not the final recipients of worship.

Gyekye asserts that "God is the supreme being but not the object of direct worship" but other deities. ${ }^{26}$ This claim does not apply to the people of Oguaa because the other seventy-seven deities are children of the Supreme Being who act as intermediaries and are not the final recipient of worship. Mbiti affirms that although worship may be directed to spirits and the ancestors, they are only regarded as intermediaries between the Supreme Being and humanity "so that he (i.e., the supreme being) is the ultimate recipient whether or not the worshippers are aware of that". ${ }^{27}$

The indigenous people have a strong belief that God is a spirit who cannot be seen yet his presence can be felt. $\mathrm{He}$ is the Supreme Being who is the creator and centre of all that there is and the mover of all. The question of whether God exists or not is never asked among the people of Oguaa. Atheism or agnosticism is not accommodated among the indigenous people of Oguaa; the atheist or agnostic will not be regarded as Nyimpa adasa. ${ }^{28}$ The implication is that the knowledge of the existence of God among the people is a commonly known fact leading to their belief in him, which is also expressed in some common names ${ }^{29}$ and maxims. ${ }^{30}$

In discussing the origin of the African belief in God, Mbiti has put forward three reasons that could have led to indigenous Africans' belief in God and these were: reflections on the creation of the universe, the realization of human limitations and weaknesses, and thirdly observation of the forces of nature. ${ }^{31}$ These may suggest that there was a point in time that the Africans did not believe in God but this cannot be said of the people of Oguaa.

\section{Indigenous Fante names of God}

Opoku posits that all African societies have specific names for God which express their idea of the uniqueness of God. ${ }^{32}$ These attributed names and appellations give a vivid insight into the people's notion and conception of God. Names are important in the Fante culture and they give specific identity to the bearers. The one who bears the name must be worthy of it and is expected to live the implication of the name. Names are believed to influence the character of the bearer. It is only those who are accepted as legitimate members of the family that are given names.

Quarcoopome identifies three Akan names of God - Onyame, Onyamkopsn, and Onyamkopon Kwame. He asserts that Onyame is derived from "nya" (to get) and " $m e$ " (satisfy) which makes it reasonable to infer that Onyame means "the God of fullness" or "the God of ultimate satisfaction." 33 In his extensive contribution to the Akan meaning of God, Danquah states three names of the Akan God and these are: Onyame (the Akan Deity), Onyamkopsn Kwame (the God of Saturday), and Ddomankoma (the infinitely manifold God). According to Danquah, "Onyame is from Nyam; shining, glory or bright and there are still people who pronounce Nyame as Nyam' in poetry." He posits that "the Akan root name for Deity is Nyam, Shining One." ${ }^{34}$ The people of Oguaa seem to affirm this position.

According to Korsah and Kuwornu-Adjaottor, the natives of Oguaa also use the three distinctive Akan names for the Supreme Being. These names bring to light their reflection on the Supreme Being. They are not revealed names in the manner of the deity instructing the people to identity and address in a specific manner. On the contrary, they are contextual names that were constructed by the indigenes as a result of their experiential encounters in varying situations of life. These Fante-Akan indigenous names are: Onyame, Onyankopon, and Ddomankoma. All others, apart from these three, are arguably attributes of the being conceived as the Supreme Being or God. ${ }^{35}$

Anthropologists such as Rattray and Field have postulated that Onyame, for the Akan and Fante, is the sky God. Until recently the sky God was not thought of as the supreme being, therefore to say that Onyame is the sky God is a wrong perception of the Akan belief in the supreme being. Once Onyame has nothing to do with the sky God, then

\footnotetext{
24 Oguaa Fetu Afahye Brochure (Cape Coast: Nyakod Printing Works, 2008)

25 The traditional festival of the people of Cape Coast (Oguaa). It is celebrated in the first week of September

26 Kwame Gyekye. African Cultural Values. (Accra: Sankofa Publishing Company, 1996), 6, 7.

7 John S. Mbiti. African Religions \& Philosophy. (London: Heinemann, 1969), 58.

It refers to a human being with a moral conscience

2 An example of such a name is Nyameakyedzi which means a gift from God

Examples include Obi nkyere abofra Nyam, which literally means no one shows the child God and Aboa onyi dua, Nyame na spra no ho, also literally means that it is God who cleanses the tailless animal

31 John S. Mbiti. Introduction to African Religion. $2^{\text {nd }}$ ed. (Oxford: Heinemann International Literature and Textbooks, 1991 ), $45,46$.

32 Kofi Asare Opoku. West African Traditional Religion (Accra: FEP International Private Limited, 1978), $14,18$.

33 T.N.O. Quarcoopome. West African Traditional Religion (Ibadan: African Universities Press.1987), 62, 63, 64.

4 Joseph B. Danquah. The Akan Doctrine of God (London: Frank Cass and Company Limited, 1968), 31-77.

35 Korsah \& Kuwornu-Adjaottor. “The Akan experience of God through the eyes of the Fante from Oguaa,"” 282.
} 
what is the meaning of such a name? It has its meaning rooted in its etymology. According to one school of thought championed by Danquah, Onyame or Nyame is derived from the word enyim-nyam literally meaning, splendour of the face, shining, bright, glory, excellency, honour, dignity. When used for mortals, enyimnyanfo translated into English is a dignified, distinguished or honourable man or woman. Onyame as a name of a supreme deity is the 'Shining One' and his nature is the shining power which is evident in one of his appellation Amowia, the giver of light or sun. From this perspective, the name could mean the most honourable and transcendental entity in society. ${ }^{36}$

Another opinion is that two words are joined to form Onyame. These words are onya meaning 'he/she/it gets' and men which means 'satisfied/satisfaction. If this is true, then the original name will be Onyamen. This will literally mean 'he/she/it is satisfied whenever he/she gets/finds/encounter/has 'that being'. The pronoun ' $O$ ' (he or she) is sometimes ignored and the name becomes Nyame. This will explain the meaning of the name better; it literally becomes 'when I get that being, I become satisfied'- "enya n'amen." Onyame as the name of a supreme deity in the minds of the people of Oguaa means 'the one who is full of satisfaction' or 'the one who is needed to attain fullness or satisfaction.' The name points to the sufficiency of the supreme being and resonates the notion that when 'you have him you need no other.'

Most of the people in Oguaa today seem not to be aware of Danquah's view. Although his etymology is traced from a different word as compared to what is held by the Oguaafo, it takes nothing away from both schools of thought. It is highly important to note that the two different sources of Onyame as a name of the Akan Deity postulate him as the most important and the most sought-after. He is indeed the Supreme Being, the all in all.

Another name for God among the people from Oguaa is Onyakopon or Onyaksrpon. The ' $O$ ' in Onyakopon or Onyakspon is a pronoun that can be ignored and does not affect the meaning of the name. The people of Oguaa as at today are divided concerning this name of the Supreme Being. A section of the people calls him Nyankopon while the other section refers to him Nyanksrpon. Nyankopon is an amalgamation of two separate Fante words and these are: the noun 'nyanko' (friend) and the suffix 'pon' (great, huge, big, etc.). 'Nyanko' is a singular word so when amalgamated with 'pon' it renders the meaning as 'a great friend'. It can be inferred that the indigenous people in their earliest days knew their supreme deity to be a great friend. When they speak of Nyankopon they mean a dependable friend who will never let them down. It is expressed in the name Twereduapon Nyankopon. This also portrays their absolute trust in depending on the Supreme Being as a deity worthy to be worshipped above all deities.

The third name used by the people is Ddomankoma; the people of Oguaa are not bothered about the etymology of the word, what matters to them is what it means. Jdomankoma, according to a court historian ${ }^{37}$ implies that God has no beginning and end. Few people try to break the name into parts to explain its meaning. In doing this, it is divided into three parts and these are 'Odo' (love), ' $m a$ ' (full), and ' $n k o$ ' (alone), this renders the meaning he who is alone yet full of love. In this breaking down of the name, the last ' $m a$ ' is not talked about because its meaning (full) does not change. This seems a later development as a result of their encounter with Christianity.

The people of Oguaa aside from the indigenous names of God have perceived various aspects of God which they consider as his very nature. Some of his essential natures are expressed in the indigenous language as follows:

1. Nyame nyi do (God is love): the indigenes experience the love of Onyame in the things he has created to support the highest form of life which is nyimpa nkwa (human life). Some examples of such are the fishes in the sea for consumption and also the plant and trees for medicinal purposes. This love is perceived to be impartial: It is said that Onyame loves all and provides for all including, those needy people in the community who do not have anyone to turn to for food or comfort. A well-known metaphorical maxim of the Fantes vividly captures this essential nature of Onyame is: abowa onyi dua Nyame na spra no ho.

2. Nyame wo abotar (God has patience): He is patient with everyone including the sinner. In the words of Jkomfo Nana Badu, "God is slow but sure". This "slowness," a mark of his enormous patience, makes some people turn to the abosom $^{39}$ for quick adjudication of urgent matters. The Gods are quick in meting out justice and severely punishing sinners.

3. Shuntahu a shuadzi nyinaa/oti nsem nyinaa: He is conceived to be an omniscient being. As a spirit, Onyame is said to see the hearts of humans. The thoughts of human beings never elude him. The tiniest insect could never escape the surveillance of Onyame. The whisperings of humans are captured and decoded by the 'ears' of Onyame.

\footnotetext{
36 Danquah. The Akan Doctrine of God. 36-39.

37 The court historian in reference is Supi Minnah who is also the Head of No. 6 Akrampa Asafo Company in Oguaa. He revealed this in an interview on 22nd July 2019.

38 A traditional priest who has been in practice for thirty-three years.

39 These are believed to be agents of Onyame charged to oversee particular jurisdiction of creation. Some are identified with aspects of nature such as sea, mountains, forests, trees, stones, etc. which are properly understood to be their holy abodes. Unlike, Onyame, these gods or deities are believed to be quick in exacting just judgments and consequences for human humans' conducts.
} 
4. Owo bia nyinaa: Onyame is conceived as an omnipresent entity or reality. He is thought of to be accessible

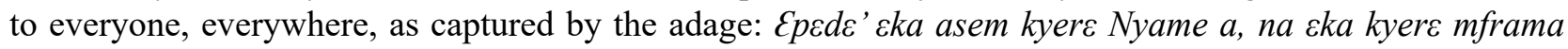
(meaning: if you want to speak to God speak to the wind). The entire universe is imbued with his everpresence influence, values, gifts, protection, and provisions. Hence, he is not represented with any symbol in any shrine. Also, indigenous believers do not attempt to restrict the presence of God to any particular location. For this reason, there is no particular shrine for Onyame in any Fante community. Anytime and anywhere a cultic activity is held, Onyame could be invoked.

5. Otumfu/Tumi wura: The possessor of all powers including that of the other deities. In brief, he is the Omnipotent. Chiefs, family heads, and all other rulers of human and supernatural realms draw their authority from Onyame. A Fante adage says Onyame na ssi ohen, na sno ara na stu ohen (God is the ultimate being who enstools/enskins and destools/deskins chiefs, queens, and all leaders). The most powerful chief/queen in the Oguaa traditional society does not compare with the majesty and royalty of Onyame.

\section{The concept of God among the Jewish and Fante People: Points of Convergence and Divergence}

Jews of the Hebrew Bible and Fante of Oguaa share basic notions in common regarding their conception of a supreme transcendental entity. In both traditions, basic questions about the existence of God and his active presence in human affairs are largely taken for granted. As already pointed out, the Jews in the Hebrew Bible perceived their YHWH God as the active source of creation and supreme head of the universe. This is evident in the statement "in the beginning YHWH God created the heavens and the earth" (Gen 1:1). The same understanding is found among the people of Oguaa. The average indigenous Fante shares in the thesis that 'the existence of God is not taught'; it is innate to the material culture of the society as well as in their maxims. ${ }^{40}$

Also, Jews in the Hebrew Bible and the people of Oguaa share a common view that God is the uncreated creator who was in existence before the beginning because he created the beginning. The YHWH of the Jews is the one who causes things 'to be'. In a similar vein, the people of Oguaa also hold onto the view that Onyame has always existed and there is no time that he did not exist. For them, the beginning and the existence of everything is in Onyame. Although both Jews of the Hebrew Bible and Fante people of Oguaa share the common notion that YHWH and Onyame/Onyankopon respectively is the creator of the universe, they do differ on the details of the creative activities of their supreme deity.

Another point of convergence is that both Jews of the Hebrew biblical eras and the Fante people of Oguaa attach great importance to the name(s) of a deity because of the supposed impact names have on the bearers. An invocation of the sacred name or appellations of the deity in critical situations is believed to move the deity or implicate him/her to attend to one's supplications. Countless examples of such invocations are found in the Hebrew Bible and Fante libation prayers. In the Jewish Scriptures, the supreme deity actually revealed himself to Moses and introduced himself as the "I am who I am" (Exodus 3:14, NRSV). This name emphasizes the fundamental nature of the deity as the supreme deity 'who is' and 'will be who he will be'. Other appellations also draw attention to other essential aspects of his nature. It seems these attributes developed from the day-to-day encounters the people have had with the deity. In the same vein, Onyame/Onyanksrpon and Jdomankoma are the respective names and supreme appellations of the highest conceivable deity of the Fante people of Oguaa. These labels seem not to have been revealed to the people of Oguaa like the label YHWH was revealed to the Jews through Moses. The indigenes of Oguaa might have assigned these terms to the Supreme Being based on their understanding and perception of his/her beingness. One can deduce that both the Jews and the people of Oguaa understood names and associated them as 'pointers' of nature and the potentialities of the deity bearing them.

The major difference is that Jews domesticated and personalised YHWH (God) as having established a unique relationship with them. Thus, they guarded the cult of YHWH against foreigners and thought that he sits in judgement against the so-called deities of the surrounding nations. Despite their notion that YHWH is the supreme deity of the universe and the source of all powers, the Jews were warned from identifying him with that which was/is worshipped in other cultures. In the case of the Fante people of Oguaa however, the Supreme Deity is not domesticated in the sense of preventing outsiders from getting access to him. Again, the Fante do not have a cult of Onyame since he is worshipped through intermediaries. Thus, in their deeds and thoughts, they do not claim any unique privilege that Onyame is theirs alone and that 'they are the chosen race of Onyame.' Onyame exists for the entire human race and they conceive that the best way to supplicate and appease him is validly through the intermediary deities.

\section{The Nature of the Supreme Being among the Jewish and Fante People}

Fante of Oguaa and Jews of the Hebrew Bible share similar notions regarding the nature of the Supreme Being. Both attribute the origin of the universe and the entirety of life within it to the creative abilities of the supreme being. The first

\footnotetext{
40 obi nkyere abofra Nyame (no one shows the child [the existence/awareness about] God)
} 
sentence of the Hebrew Bible asserts that he is the uncreated source of the universe (Gen. 1:1) and the orderliness of its contents. This notion of God is shared by the Oguaa people. Their oral narratives give a vivid portrayal of the supreme deity as Dboadze Nyame (God the Creator).

The underlining difference is in the monotheistic nature of God in the Hebrew Bible. Unlike the Jews who are consistently cautioned and encouraged not to entertain, solicit assistance nor show gratitude to any other deity, it is a conventional practice of the people of Oguaa to acknowledge and solicit for assistance from other deities in addition to Onyame. The act of seeking spiritual help from the intermediary ministers of Onyame does not create confusion in the mind of the Fante people of Oguaa regarding the tripartite attributes: all-powerful, all-knowing, and all-loving. However, Jewish prophets detested such practices in strong-worded terms. In one of such texts, YHWH asserts "I am the first and I am the last; besides me, there is no god. Who is like me? Let them proclaim it, let them declare and set forth before me. Who has announced from of old the things to come? Let them tell us what is yet to be" (Isaiah 44:6, 7). In short, the people of Oguaa proclaim the oneness of God and his supremacy over all creation including the other deities who are believed to be his children (the seventy-seven) while the Jews completely deny the thought that other deities exist with and beside Yahweh.

Most ancient cultures had symbolic metaphors for the supreme deity. In Greek mythology, for instance, Zeus was depicted by a statue of a giant masculine figure wielding a thunderbolt. The Mediterranean cultures made statues and other forms of images to represent divine figures including the supreme deity. Before the formation of the confederate at Sinai, the patriarchs erected altars for their El (God) at every spot a hierophanic experience occurred. However, the Jews were cautioned by Moses and the prophets to resist the influence of representing YHWH God in any form of an image. This measure was taken to refute the notion that YHWH could be confined to a particular shrine. The only item that symbolised the mighty presence of YHWH was the ark of the covenant. Among the Fante people of Oguaa, there are no rules against the representation of Onyame, yet their conception of his nature has never suggested to them to thinking of material representation. Whereas they have numerous individual shrines and images for the lesser deities (i.e., the intermediary ministers), there is no particular shrine for Onyame due to the people's understanding of the omnipresence nature of God. The seventy-seven recognized deities of the Fante people of Oguaa dwell in various natural objects such as rocks, trees, water bodies, mountains, etc. While YHWH had a high priest that attended to his cult and sacrifices and mediated between him and the Jews, the Onyame of the Fante people of Oguaa has never had such a priest although there are priests that attend to the cults of the lesser deities.

The Jews conceive of a living God who is the source of human life and interacts directly with his people. God in the life and thought of the people of Oguaa is that of a living God who gives life to humans and this makes it a grievous offence against the land to kill or even attempt to commit suicide. Again, the voice of Yahweh is heard loud and clear through the prophets: while God in the Hebrew Bible interacts with his people through the prophets and the priests, Onyame does so with the people of Oguaa through the deities who serve as intermediaries.

The nature of God in the Hebrew Bible is that he is full of activities. The Hebrew Bible portrays him as a being always in motion. YHWH God journeyed along with his people and never departed from them, even when they had exhibited grave faithlessness. His activities with the Israelites reveal his nature as a faithful deity who took personal initiatives to bring glory to himself through the historical experiences of the Jews, both 'in thick and thin.' This is seen from the way and manner the Israelites interpreted their national experiences in the light of the relationship with their covenanted deity, YHWH. The people of Oguaa do not conceive Onyame to be actively involved in their national experiences. Onyame was not domesticated in the Fante confederation as YHWH was in the Israelite confederate. Fantes express the belief that although God is interested in their activities, he is not much involved in it because he has charged the seventy-seven ministers to do that on his behalf. Thus, the people of Oguaa acknowledge the activeness of Onyame through the other deities.

The Hebrew Bible and the people of Oguaa accept the notion that the supreme deity is the source of love. The people of Oguaa say Nyame nyi ds (God is love). For them, the love of Onyame is realized in his provision for all. For instance, he provides rain and sun for all creation to benefit regardless of the poor, rich, great, small, sinner, and righteous. The Hebrew Bible also expresses the love of God for his people not only through his provision but also his redemptive acts of liberating the Jews from enslavements and occupations.

Again, both the Jews and the indigenes of Oguaa believe in the threefold nature of the supreme deity omnipresence, omniscience, and omnipotence. It is as a result of their belief in the supreme deity's omnipresence which is why the people of Oguaa do not have a particular shrine noted for invoking Onyaksrpon. For them, God is everywhere and can be worshipped everywhere and anywhere. The people of Oguaa express his omnipresence in a maxim $^{41}$ about the wind. The presence of God is compared to the wind or the air, thus, wherever there is air then there is God. The Jews also believe in Yahweh's omnipresence. Although a temple was built for him, his presence and power are not limited to the temple.

\footnotetext{
${ }_{41} \quad$ Epede'cka asem kyere Nyame a, na eka kyere mframa (meaning: if you want to speak to God speak to the wind)
} 
The omnipotence of YHWH God is acknowledged by the Jews in the Hebrew Bible. It is believed that the Jewish kings were enthroned and dethroned by Yahweh. Saul the first king was chosen by God and upon his disobedience was later rejected by God. The people of Oguaa also share the belief that God is the kingmaker and he is also the King above all kings. They express this in the following maxims respectively: "Onyame na osi hen" and "Onyame nyi hen. The most powerful person in Oguaa traditional area is the chief. Since chiefs and queens are enstooled by Onyame, then it follows that Onyame's power transcends theirs in every realm of life.

The notion of the Supreme Being as the king of kings gives support to the view that he is a just arbitrator. The Jews consider YHWH God as that fatherly figure who deals justly and mercifully with those who oppress the weak. The Hebrew Bible stresses God's justice for all humankind. The Jews are exhorted to be just as their YHWH God in all their dealings. Jehoshaphat admonished the judges of his time in the following words: "Consider what you are doing, for you judge not on behalf of human beings but the LORD'S behalf; he is with you in giving judgment. Now, let the fear of the LORD be upon you; take care what you do, for there is no perversion of justice with the Lord our God, or partiality, or taking of bribes" (2 Chronicles 19:7, NRSV). The people of Oguaa also express a similar belief in some of their maxims such as: 'Nyame na ska kunafo asem ma no' (God is an intercessor/comforter of the widow) and also 'Nyame botua wo kaw' (in the literal sense, God will repay you justly). This is a serious pronouncement made when one feels treated unjustly. The one who makes such pronouncement actually invokes the justice of Onyankorpon and seeks justice for all including the oppressor.

Lastly, the Jews believe children are gifts from YHWH God. Abraham and Sarah perceived Isaac their son to be a gift from God. Hannah also believed that Samuel was also a gift. In 1 Samuel 1:5, the writer says "the LORD had made her barren" which exhibits their belief in God who gives children as gifts. The people of Oguaa share this thought; it is expressed in some of the names they give to their children. The most commonly known one is Nyamekye (God's gift). Nyamekye is derived from Nyame and akyedze (gift). The Jewish concept of YHWH God in the Hebrew Scripture has close affinities with the concept of Onyame among the people of Oguaa. Nevertheless, Jews' ideas about the supreme deity lean towards strict monotheism while that of the Fante from Oguaa exhibits a kind of "modified monotheism". ${ }^{42}$

\section{CONCLUSION}

From the above discussion, the authors support the proposition that Onyame/Onyankopon/Odomankoma and YHWH are conceived, acknowledged, and worshipped on equal tangents as the Supreme Deity by the Fante of Oguaa and Jews of Hebrew Bible respectively. The Jews believe that the power of their God transcends all other immortal beings and he is not restricted to a particular nation. The same idea is well enshrined in the life and thought of the Fante from Oguaa: Onyame is beyond their shores because he is Jboadze (the creator of all). It is of no surprise that both the Jews and the people of Oguaa acknowledge that God is omniscient, omnipotent, and omnipresent. The nature of God expressed in the Hebrew Bible and the worldview of the Fante of Oguaa correlates in many details. The minor differences stem only from the subject of exclusive devotion to the supreme deity, which is proclaimed by Jews as monotheistic worship of YHWH God. From this logical line of reasoning, it is cogent to assert that the seemingly polytheistic or better still henotheistic nature of the indigenous faith of the Fante people of Oguaa does not negatively affect the common notions they share with the Jewish faith as in the Hebrew Bible regarding nature, being, appellations, and activities of the supreme deity in their religious worldviews.

\section{ABOUT AUTHORS}

LEO ANDOH KORSAH holds a Bachelor of Arts and a Master of Philosophy degrees from the Department of Religious Studies at the Kwame Nkrumah University of Science and Technology (KNUST), Kumasi, Ghana and a Post Graduate Certificate in Education (PGCE) from the University of Cape Coast (UCC) Ghana. He is a Senior Tutor at the Methodist College of Education, Akyem Asene-Aboabo, Oda- Eastern Region - Ghana.

MAXWELL KOJO TSIBU is a PhD candidate at the Department of Religion and Human Values. He holds B.Ed. and Master of Philosophy degrees from the same Department at the University of Cape Coast (UCC). He is a Tutor at the Methodist College of Education, Akyem Asene-Aboabo, Oda- Eastern Region - Ghana. Email: maxwelltsibu.k@gmail. com.

\footnotetext{
42 Bolaji E. Idowu, African Traditional Religion: A definition. (SCM Press Ltd, 1973), 40.
} 


\section{BIBLIOGRAPHY}

Asare-Danso, S. African Traditional Religion. Cape Coast: Beret Outlook Press, 2019.

Brown, F., Driver. S.R. \& Briggs, C.A. A Hebrew and English Lexicon of the Old Testament.England, 1907.

Danquah, J. B. The Akan Doctrine of God. London: Frank Cass and Company Limited, 1968.

Gyekye, K. African Cultural Values. Accra: Sankofa Publishing Company, 1996.

Hick, J. Philosophy of Religion. N. J: Eaglewood Cliffs, 1983.

Idowu, E.B. African Traditional Religion: A definition. SCM Press Ltd, 1973.

Johnson, A. R. The one and many in the Israelite conception of God. Cardiff: University of Wales Press, 1961.

Jonas, H. The Concept of God After Auschwitz: A Jewish Voice. New School for Social Research. The University of Chicago, 1987.

Korsah, L.A, \& Kuwornu-Adjaottor, J.E.T. The Akan experience of God through the eyes of the Fante from Oguaa. Art Human Open Acc J. 2019; 3(6):280-283. DOI: 10.15406/ahoaj.2019.03.00142

Laurence, S. \& Margolis, E. Concepts: Core Readings. Massachusetts: MIT Press, 1999.

Maimonides, M. B. Guide of the perplexed. Translated and Edited by Shlomo Pines. Chicago: University of Chicago Press, 1963.

Mbiti, J.S. Introduction to African Religion. $2^{\text {nd }}$ ed. Oxford: Heinemann International Literature and Textbooks, 1991.

Mbiti, J.S. African Religions \& Philosophy. London: Heinemann, 1969.

Microsoft. Microsoft Encarta Dictionary. Microsoft Corporation, 2008.

Miller, P.D. The Religion of Ancient Israel. Westminster: John Knox Press, 2000.

Obiorah, J. M. The Biblical foundations of Christian Monotheism. In B. U. Ukwuije (Ed.) God, Bible and African Traditional Religion - Acts of SIST International Missiological Symposium. Enugu: SNAAP, 2010.

Ogada, C. The Judeo-Christian God. In E. E. Onyedinma (Ed.), Whose God is God? Exploring the Concept of God within Religions. Abuja, Nigeria: Adonis \& Abbey Publishers Ltd, 2013.

Oguaa Fetu Afahye Brochure. Cape Coast: Nyakod Printing Works, 2008.

Opoku, K.A. West African Traditional Religion. Accra: FEP International Private Limited, 1978.

Pobee, J.S. Toward an African theology. Nashville: Abingdon Press, 1979.

Prasad, S. The concept of God in the Philosophy of Kant. India, New Delhi: Classical Publishing Company, 2005.

Quarcoopome, T.N.O. West African Traditional Religion. Ibadan: African Universities Press, 1987.

Ross, J. J. The primacy of the Personalist Concept of God in Jewish thought. The Journal of Jewish Thought and Philosophy, 8, pp. 171-199, 1999.

Schäfer, P. Two Gods in Heaven: Jewish conception of God in antiquity. New Jersey: Princeton University Press, 2020.

Schmaus, M. DOGMA 2: God and Creation. London: Sheed and Ward Inc, 1969.

Smith, E. W. African Ideas of God, 2nd ed., London: Edinburgh House Press, 1961.

Vaux, R. The religion of the O.T. In R. Tricot (Ed.), New Catholic Encyclopaedia (Vol. 6, Part 2, pp. 393-422). Washington D.C: Catholic University of America, 1967. 